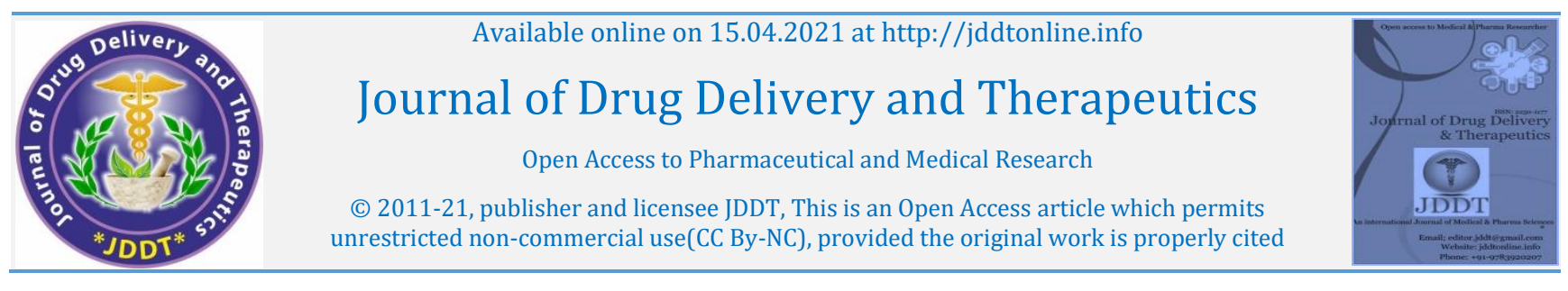

Open Access Full Text Article

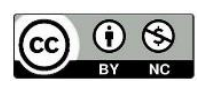

Review Paper

\title{
A Systematic Review on Various Therapeutic Options for Coronavirus Outbreak
}

\author{
Sharib Raza Khan ${ }^{1}$, Babita Sharma ${ }^{1}$, Sankha Bhattacharya ${ }^{2 *}$ (D) \\ ${ }^{1}$ Department of Pharmaceutical Analysis, ISF College of Pharmacy, Moga, Punjab, India \\ ${ }^{2}$ Department of Pharmaceutics, School of Pharmacy \& Technology Management, SVKM'S NMIMS Deemed-to-be University, Shirpur, Maharashtra, \\ India
}

\section{Article Info:}

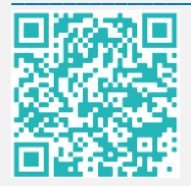

\section{Article History:}

Received 19 Feb 2021

Review Completed 26 March 2021

Accepted 06 April 2021

Available online 15 April 2021

\section{Cite this article as:}

Khan SR, Sharma B, Bhattacharya S, A Systematic Review on Various Therapeutic Options for

Coronavirus Outbreak, Journal of Drug Delivery and Therapeutics. 2021; 11(2-s):185-194

DOI: http://dx.doi.org/10.22270/jddt.v11i2-s.4650

\section{Abstract}

SARS-CoV-2 (Severe Acute Respiratory Syndrome Coronavirus-2) or coronavirus disease that emerged in Wuhan, China's Hubei province. According to a Wuhan citizen, the virus spread from the Wuhan fish market to humans via a form of waterborne transmission. The WHO proclaimed the SARS-CoV-2 Pandemic a global public health emergency in March of the following year. Rather than influencing the individual animals mostly, the movement of humans and a few days later, the infection spread to other parts of the world by the distribution of specimens to animals and by the movement of humans, causing considerable illness in human populations. An estimated one and a total of nearly sixtyeight million two hundred and fifty-six million people have been impacted, including one and a million thousand five hundred and sixty thousand fatalities in more than two hundred countries around the world. As of the present, there are no medicines or vaccinations against the world's first SARS-CoV-2 virus are in clinical trials molecular and cellular studies of CoVs, as well as their care, were reviewed in this latest assessment.

Keywords: SARS-CoV-2, WHO, Global pandemic, Human coronaviruses, Pathogenesis, Treatments

\section{*Address for Correspondence:}

Dr Sankha Bhattacharya, Associate professor, Department of Pharmaceutics, School of Pharmacy \& Technology Management, SVKM'S NMIMS Deemed-to-be University, Shirpur, Maharashtra 425405, India. ORCID ID: 0000-0002-0771-9582 Scopus ID: 57193884937

\section{Introduction:}

China informed the World Health Organization about clustered cases of pneumonia of unknown cause on December 31, 2019, among the peoples of Wuhan City, Hubei province ${ }^{1}$. Firstly, 27 cases of unknown pneumonia were investigated which further increased up to 41 patients on January 11, 2020, with 7 severe cases and one death. Currently, the virus has an outreach to many other countries and also across the mainland of China ${ }^{2}$. On January 7, 2020, a government and national level technical organization named, "Chinese Centre for Disease Control and Prevention" (CCDC) confirmed this infection as coronavirus infection 3. On February 11, 2020, the WHO issued a statement saying Chinese researchers have made a "preliminary determination" and confirmed it as a Novel Coronavirus 4 . Later, the WHO declared a new title to this epidemic disease as 2019-new coronavirus disease (2019nCoV and now known as COVID-19 ${ }^{5}$. As of December 31, 2020, COVID-19 has influenced more than 84 million patients in 210 nations and domains around the globe and two universal movements and caused around 1.83 million deaths around the world. In India, as of December 31, 2020,
COVID-19 has influenced more than 10.3 million patients and left around $149 \mathrm{~K}$ deaths ${ }^{6}$.

Coronaviruses are a group of RNA virus which causes an infection from less serious normal cold to extreme cold or illnesses, for example, Severe Acute Respiratory Syndrome (SARS) and Middle East Respiratory Syndrome (MERS) condition 7 . The coronavirus belongs to the family Coronaviridae, subfamily Orthocoronaviridae, and order Nidovirales 8. As coronavirus are wrapped infections and have a positive-sense of single-abandoned RNA genome with a nucleocapsid of helical evenness ${ }^{9}$. The genomic size of coronavirus differs from 26 to 32 kilobase and the hatching time frame for human coronavirus is 2-14 days. As we know that the coronavirus disease is a transferable disease which mainly spread by droplet infections like coughing, sneezing as well as direct contact with various infected surfaces such as tables, desks, doors, etc 10 .

The clinical prevalence of this disease ranges from no symptom (beings asymptomatic) to severe symptoms such as pneumonia and death ${ }^{11}$. The symptom of coronavirus is fever, dry cough, fatigue, sputum production, shortness of breath, chills, nasal congestion, conjunctival congestion, diarrhea, covid toes, and blood clotting ${ }^{12}$. So, in this context, 
we have looked into the present scenario with potential reflections on the description of Human Coronaviruses (CoVs), pathogenesis, diagnostics, and available treatment options available at the national and worldwide level ${ }^{13}$. This exhaustive survey will aid improvement of general public health that will further give better administration of therapeutic drugs to combat viral disease.

\section{Description of Human Coronaviruses (CoVs)}

Coronaviruses are the enveloped viruses that have a positive-sense that can infect humans as well as animals. It belongs to the family Coronaviridae, subfamily Orthocoronaviridae, and order Nidovirales 14. The phylogenetic examination reveals that the human coronaviruses fall into the subgenus Sarbecovirus of variety Betacoronavirus which incorporates coronaviruses (SARS-
$\mathrm{CoV}$, Bat SARS-like CoV, and others) that found in people, bats, and other wild creatures ${ }^{15}$. It is classified into four genera such as alpha-coronavirus, beta-coronavirus, deltacoronavirus, and gamma-coronavirus, where alpha and beta are responsible for causing infection in humans and mammals. There are seven strains of human coronaviruses, among them, four-strain are human coronaviruses (Serotype 229E, Serotype0C43, Serotype NL63and Serotype HUK1) that are prevalent to cause moderate to gentle respiratory tract infections in people ${ }^{15}$. Another two different strains, for example, SARS-CoV and MERS-CoV are zoonotic in origin which comes out as a significant reason for respiratory illness in China and Saudi Arabia in the years 2003 and 2012 respectively. The detailed outline of Human Coronaviruses (CoVs) and their possible zoonotic causes explained in Figure 1.

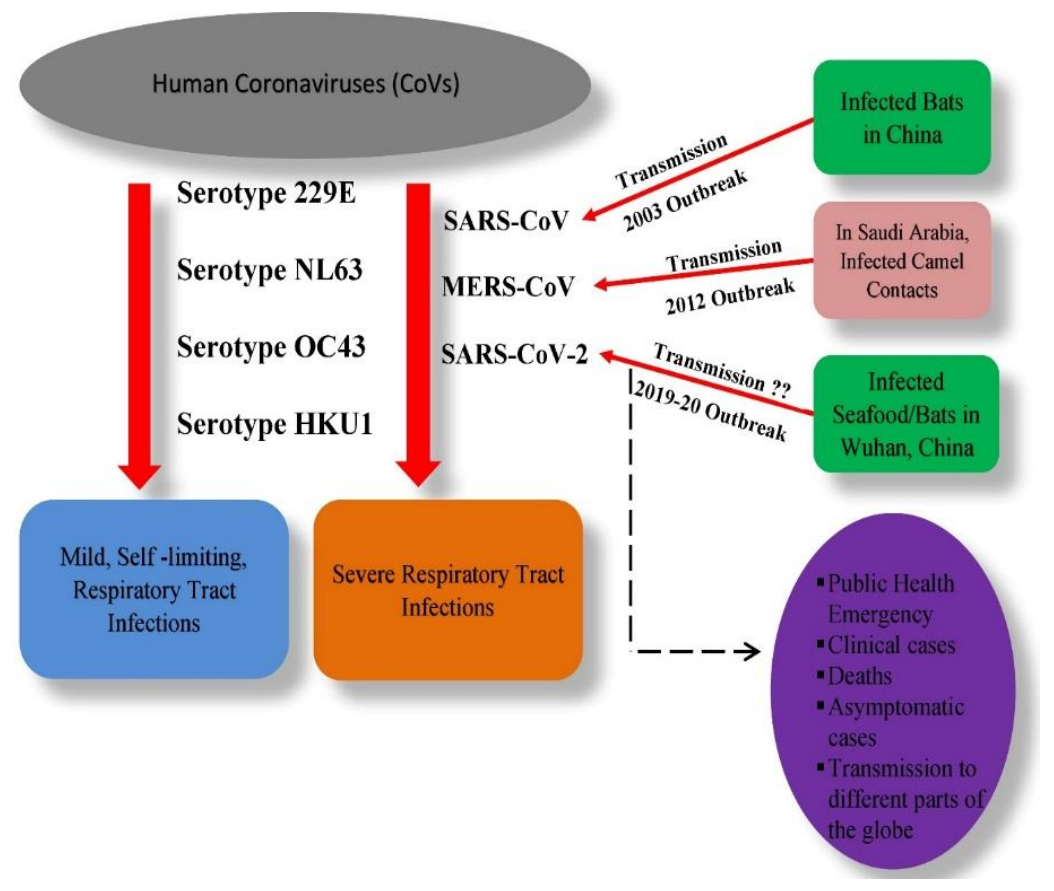

Figure 1: Description of Human Coronaviruses (CoVs)

\section{Human Coronaviruses (CoVs) Pathogenesis}

The patients of coronaviruses show symptoms similar to SARS-CoV and MERS-CoV infections, for example, myalgia dyspnoea, weakness, ordinary or diminished degree of leukocyte, fever, and non-productive cough. The pathogenesis of SARS-CoV-2 infection is poorly understood but the mechanism of SARS-CoV and MERS-CoV gave a thought regarding the pathogenesis of SARS CoV-2 infection 16. The pathogenesis of SARS-CoV-2 starts with the entry of viruses into the alveolar epithelial cells which replicates quickly and triggers a strong invulnerable reaction that brings cytokine storm conditions and pulmonary tissue harm. The cytokine storm conditions are commonly called hypercytokinaemia in which the uncontrolled production of pro-inflammatory cytokines responsible for Intense Respiratory Pain Disorder (ARDS) and numerous organ failures ${ }^{17}$. Additionally, the cellular and humoral immunity stimulate antigen presentation which is mediated by virusspecific B cells and T cells, and the number of T-cells, CD4 + T-cells, and CD8 + T-cells are declined in SARS-CoV-2 infected patients. After that T-cells undergo functional depletion, resulting in the least resistant capacity for SARSCoV-2 infection, acute respiratory distress syndrome, decreased immune system, as well as the secondary infection further, leads to respiratory failure ${ }^{17}$. The pathogenesis of Human Coronaviruses (CoVs) and their fundamentals are explained in Figure 2. 


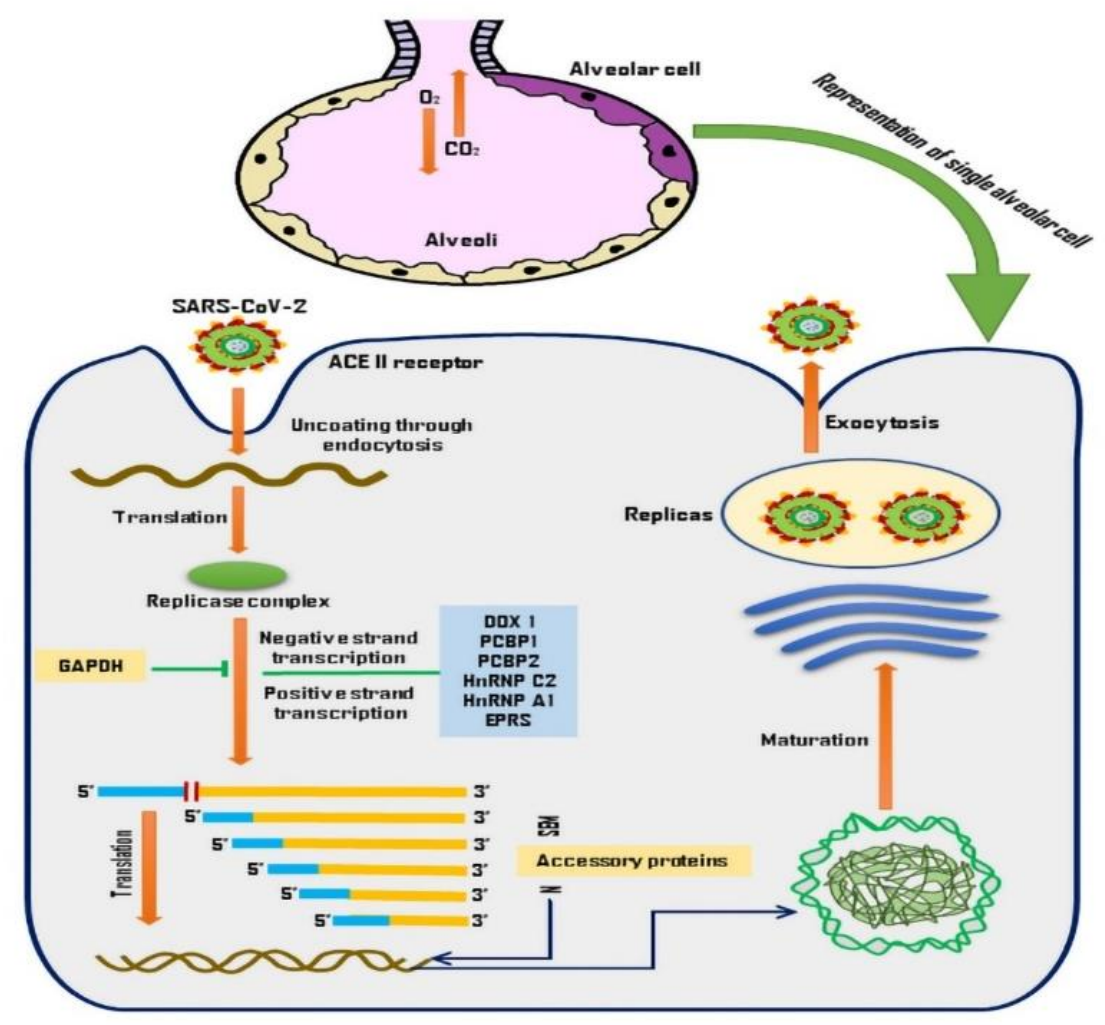

Figure 2: Human Coronaviruses (CoVs) Pathogenesis

\section{Treatments}

The suspected and confirmed cases of coronavirus infection should be treated with effective isolation and protective conditions in designated hospitals. The suspected cases should be treated in an isolated or single room whereas the confirmed cases can be treated in the same ward as well as the critical cases should be admitted to the Intensive Care Unit (ICU) as soon as possible. The common therapy for coronavirus infections is bed rest including supportive therapy like oxygen therapy, maintenance of proper airways, breathing, circulation, ventilation if required (if $\mathrm{PO}_{2}<55 \%$ ), isolation to prevent its spread, correction of electrolyte imbalance, correct temperature as well as the utilization of broad-spectrum antibiotics to prevent secondary bacterial infections ${ }^{18}$. A number of pre-existing drugs mainly the antiviral drugs are being available and exploited for the treatment of coronavirus infection which has been shown in Fig 3 (a) and 3 (b).<smiles>CCN(CC)CCNc1ccnc2cc(Cl)ccc12</smiles>

Chloroquine<smiles>CCN(CCO)CCCC(C)Nc1ccnc2cc(Cl)ccc12</smiles>

Hydroxychloroquine<smiles>Cc1cccc(C)c1OCC(=O)N[C@H](Cc1ccccc1)[C@H](O)C[C@@H](Cc1ccccc1)NC(=O)[C@@H](C(C)C)N1CCCNC1=O</smiles><smiles>CC(C)c1nc(CN(C)C(=O)N[C@H](C(=O)NC(Cc2ccccc2)C[C@H](O)[C@@H](Cc2ccccc2)NC(=O)OCc2cncs2)C(C)C)cs1</smiles>

Ritonavir

Figure 3(a): Chemical Structure of Drugs used in COVID-19 Treatment 
<smiles>NC(=O)c1ncn([C@@H]2O[C@H](CO)[C@@H](O)[C@H]2O)n1</smiles><smiles>CCC(CC)COC(=O)[C@H](C)NP(=O)(OC[C@H]1O[C@@](C#N)(c2ccc3c(N)ncnn23)[C@H](O)[C@@H]1O)Oc1ccccc1</smiles>

Remdesivir<smiles>NC(=O)c1nc(F)c[nH]c1=O</smiles><smiles>CCOC(=O)c1c(CSc2ccccc2)n(C)c2cc(Br)c(O)c(CN(C)C)c12</smiles>

Arbidol<smiles></smiles>

Darunavir

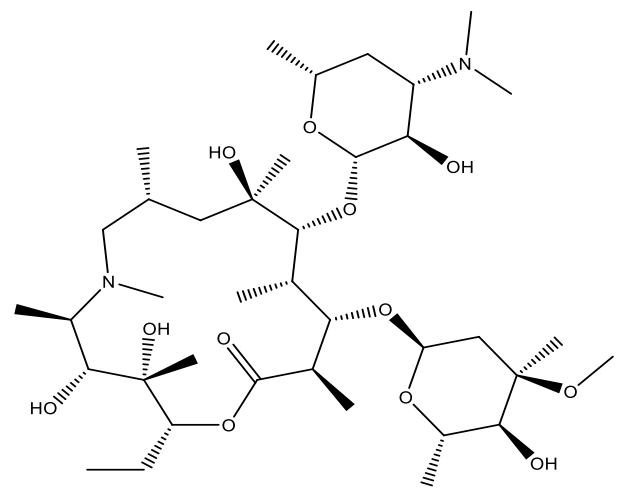

Azithromycin

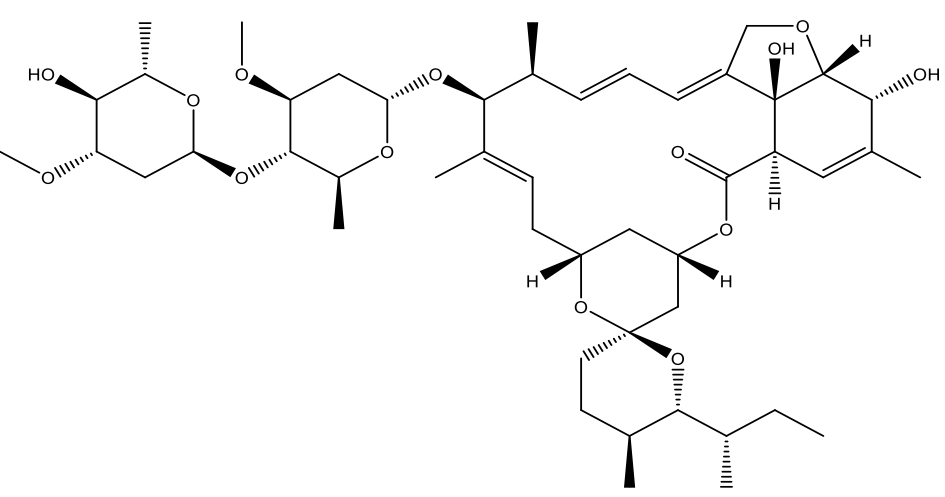

Ivermectin<smiles>CCOC(=O)[C@H](CCc1ccccc1)N[C@@H](C)C(=O)N1CCC[C@H]1C(=O)O</smiles>

Enalapril<smiles></smiles>

Dexamethasone<smiles>CC(C)Cc1ccc(C(C)C(=O)O)cc1</smiles>

Ibuprofen<smiles>CC(=O)Nc1ccc(O)cc1</smiles>

Acetaminophen

Figure 3(b): Chemical Structure of Drugs used in COVID-19 Treatment 


\section{Chloroquine and Hydroxychloroquine}

It is widely used in malarial infection, autoimmune disorder, chemoprophylaxis in certain inflammatory conditions like rheumatoid arthritis, lupus, and blood disorder porphyria cutanea tarda respectively 19 Chloroquine has shown its effects against various types of RNA virus i.e., hepatitis $A$ and $C$, rabies, polio, HIV, influenza type A and B, Zika, Nipah, and Ebola viruses, and also show some lethal effects against DNA viruses such as hepatitis B and herpes simplex virus 20. The mode of action of chloroquine and its derivatives against SARS-CoV-2 infection has multiple actions in which step by step firstly it inhibits the pre-entry of virus penetration within the cell surface receptors, inhibits the viral enzymes procedures, for example, viral DNA and RNA polymerase processes, blockade of viral entry by inhibiting glycosylation of viral proteins in host receptors, assembly of the virus, transport of new virus particle, lastly the after-virus release 21 . The alternate mode of action is by the inhibition of angiotensinconverting enzyme-2 cellular receptor, afterward acidification of the virus at the cell membrane surface, therefore, block viral fusion and also shows some immunomodulatory effects by cytokines inhibition in the host cells 22. In China, Per Gao et al. showed the in vitro activity of chloroquine and its derivatives against SARS-CoV and SARS-CoV-2 infection and the treatment outcomes from 100 patients have shown that chloroquine had better results compared to control medicament by restraining the intensification of pneumonia, improving lung imaging discoveries and shortening the ailment course ${ }^{23}$.

\section{Lopinavir and Ritonavir}

It is a Human Immunodeficiency Virus-1 (HIV-1) protease inhibitor known as protease inhibitor which sold under the name Kaletra by AbbVie intended to treat HIV-AIDS that meddles in replication and synthesis of Human Immunodeficiency Virus (HIV), prompting the creation of juvenile, non-irresistible infection particles 24. In 2003, lopinavir/ritonavir shows its activity against SARS-CoV and related to progress in certain patients. The investigation study revealed that lopinavir and ritonavir bind to the endopeptidase $\mathrm{C} 30$ of SARS-CoV-2 and hinders the protease enzyme responsible for viral replication and antiviral impact by protein synthesis restraint 25 . In the in vitro efficacy study of 47 patients treated with lopinavir/ritonavir combination and the control treatment of pneumonia-related adjuvant medications alone, the combination treatment with lopinavir/ritonavir and adjuvant medications has a progressively obvious remedial impact in bringing down the internal body temperature and re-establishing typical physiological function with no apparent toxic effects 26. Taking into account these conclusions, the beneficial outcome shows that the utilization of lopinavir/ritonavir joined with pneumoniarelated adjuvant medications in clinical treatment ought to be promoted. As per WHO, there might be a few advantages of utilizing lopinavir/ritonavir with different medications, for example, interferon- $\beta$, oseltamivir, or ribavirin ${ }^{27}$.

\section{Darunavir/ Cobicistat}

It is another class of Human Immunodeficiency Virus-1 (HIV-1) protease inhibitor but its mode of action is similar to lopinavir and ritonavir ${ }^{28}$. In February 2020, the in vitro study by Chinese researchers Dong et al. showed that darunavir significantly inhibits SARS-CoV-2 replication and its inhibition efficacy was more than that in the untreated group by 280 -fold 29 . It is currently being evaluated in a clinical trial under the name NCT04252274.

\section{Ribavirin}

Ribavirin a nucleoside derivative with broad-spectrum antiviral activity used to treat a few viral infections like Hepatitis C, Respiratory Syncytial Virus (RSV), and Viral Haemorrhagic Fever (VHF) ${ }^{30}$. The replication of RNA and DNA infections is forestalled by inhibiting Inosine Monophosphate Dehydrogenase (IMD), which requires the synthesis of Guanosine Triphosphate (GTP) ${ }^{31}$. In the year 2003, Ribavirin was broadly used to treat SARS-CoV infected patients and utilized clinically in combination with corticosteroids or interferon in Hong Kong. Wang et al. studied the in vitro activity of ribavirin against SARS-CoV-2 infection and found that an EC50 of $109.5 \mu \mathrm{M}$, which was 100 times more potent and less potent than Remdesivir 32 . The ribavirin shows the unfortunate antagonistic impact of diminishing hemoglobin in respiratory pain patients at high dose exceeds potential clinical advantage and, in this way, ribavirin was not considered as a suitable medication for additional research by World Health Organization 33 .

\section{Favipiravir}

It is an RNA-subordinate RNA polymerase inhibitor with a wide range of antiviral action recently known as T-705 which is a prodrug of purine nucleotide Favipiravir Ribofuranosyl-5'-Triphosphate that changes into phosphoribosylated active form which restrains the RNA polymerase by ending viral replication and shows in vitro action against Influenza A, B, and C, Ebola virus, and against RNA infections ${ }^{34}$. Recently, researchers have found in vitro efficacy of Favipiravir in Chinese patients against SARS-CoV2 infection at a higher dosing range contrasted with Ebola infection despite comparable high EC50 values ${ }^{35}$. In March 2020, China endorsed Favipiravir for the treatment of SARSCoV-2 disease and as of now being under Clinical Trial NCT04273763 for patients with SARS-CoV-2 infection and currently available in Japan for the treatment of Influenza flu 36. However, it is not available in the United States for clinical use because of the absence of FDA approval.

\section{Remdesivir}

It is a prodrug of Remdesivir-triphosphate (RDV-TP) of an adenosine analog known as GS-5734 that undergoes metabolism to an active $\mathrm{C}$-adenosine nucleoside triphosphate form that inhibits RNA-dependent RNA polymerases competes with adenosine-triphosphate for consolidation into viral RNA chains at position 1 of RDV-TP eventually ends RNA synthesis at position $1+3$ and blocks viral RNA synthesis ${ }^{37}$. It shows a wide array of antiviral activity against RNA viruses including Filoviridae, Paramyxoviridae, Pneumoviridae, and Orthocoronoviridae (SARS-CoV and MERS-CoV) ${ }^{38}$. Recently, the Washington Department of Health administrated Remdesivir intravenously and found that Remdesivir shows potential activity in SARS-CoV-2 infection, at that point in vitro study of Remdesivir and Chloroquine exhibited to inhibit SARSCoV-2 infection and shows benefits in the treatment of SARS-CoV-2 pneumonia ${ }^{39}$. Clinical trials are ongoing to evaluate the safety and efficacy of Remdesivir in SARS-CoV2 patients with mild, moderate, or severe infection (NCT04292899, NCT04292730, NCT04257656, NCT04252664, NCT04280705) 40. On 1 May 2020, U.S. Food and Drug Administration (FDA) approved Remdesivir in the treatment of SARS-CoV-2 hospitalized patients and is now affirmed by USFDA for the treatment of SARS-CoV-2 infection.

\section{Arbidol (Umifenovir)}

It is also an antiviral drug against influenza flu generally utilized in Russia and China. The in vitro investigation of 
Arbidol and Arbidol mesylate indicated a strong inhibitory activity in diminishing the reproduction of SARS-CoV infection 41 . Low-level proof including a review study, case reports, and case arrangement uncovered that arbidol alone or combined with antiviral drugs created certain advantages in the treatment of SARS-CoV-2 pneumonia. In China, many randomized controlled clinical trials are proceeding to examine the efficacy of Arbidol in SARS-CoV-2 pneumonia 42.

\section{Oseltamivir}

It is another class of antiviral drug having movement against influenza flu which is a neuraminidase enzyme inhibitor that acts as a potential treatment alternative for SARS-CoV-2 infection ${ }^{43}$. Oseltamivir was not focused as a treatment option for SARS CoV-2 infection, however the absence of information on the causative pathogen at the time of treatment and the craving to experimentally treat influenza flu 44. In Wuhan, China Huang et al. exacerbated the underlying report from patients who dealt with SARS-CoV-2 infection got oseltamivir alongside with broad-spectrum antimicrobials and the results showed that no in vitro activity of oseltamivir accounted against SARS CoV-2 infection along with antimicrobials drugs 45 .

\section{Interferon Alpha (IFN $\alpha$ )}

IFN $\alpha$ is a family member of IFNs-type 1 which plays an important role in host resistance to viral infection. It suppresses viral infection by directly interfering with a copy of viruses by promoting adaptive immune responses 46. Interferon- $\alpha$ and $-\beta$ have been studied for novel coronaviruses, while interferon- $\beta$ showed its activity against MERS infection ${ }^{47}$. In vitro experiments showed that IFN $\alpha$ effectively inhibits SARS-CoV replication and has been reported that Cynomol-gus monkeys are protected from SARS-CoV infection by treatment with IFN $\alpha{ }^{48}$. Most reported result of published studies shows that the treatment combined with Lopinavir/Ritonavir or Ribavirin. Additionally, the therapeutic advantage of IFN $\alpha$ for patients with SARS was shown in a pilot-scale clinical trial. So, in this manner, IFN $\alpha$ ought to be viewed as a suitable therapy for SARS-CoV-2 infection ${ }^{49}$.

\section{Tocilizumab}

A monoclonal antibody derivative marketed as Actemra that inhibits IL-6-mediated signals by competitively binds to membrane-bound and soluble IL- 6 receptors, a proinflammatory cytokine that is engaged with differing physiological procedures, for example, T-cell enactment, immunoglobulin secretion induction, hepatic acute-phase protein synthesis initiation, and hematopoietic precursor cell multiplication and separation incitement 50. In China, Xiaoling Xu et al. used tocilizumab on 21 severe SARS-CoV2 infected patients, showed big changes in lymphocytes count, C-reactive protein levels, and also reduced oxygen intake suggests positive outcomes that tocilizumab is effective in the treatment of severe SARS-CoV-2 patients, which provided a new therapeutic strategy for this fatal infectious disease and officially under Phase 3 clinical trial 51.

\section{Siltuximab}

It is also an IL-6 targeted monoclonal Ab drug that inhibits IL-6-mediated signals same as tocilizumab and has been approved by the Food and Drug Administration (FDA) as well as the European Medicines Agency (EMA) in the treatment of Multicentric Castleman Disease (MCD) who are Human Immunodeficiency Virus (HIV) and Human Herpesvirus-8 (HHV-8) negative ${ }^{52}$. The study suggests that patients with SARS-CoV-2 infection may respond to the overproduction of IL-6 leading to a cytokine storm, caused serious lung injuries, or Acute Respiratory Distress Syndrome (ARDS). Therefore, potentially reducing SARSCoV-2 disease progression with Siltuximab may prevent patients from serious symptoms and entering ITU also allow patients to leave the ITU at an earlier stage. In Italy, Gritti G et. al and its colleague's studies show evidence of benefits in 21 patients of SARS-CoV-2 infection by use of intravenous Siltuximab showed reduced CRP levels, 33\% showed clinical improvement, $43 \%$ stabilized, and $24 \%$ worsened after 8 days and those patients who experienced a worsening in their condition, one patient died, and one patient experienced a cerebrovascular event ${ }^{53}$.

\section{Ivermectin}

Ivermectin is a broad-spectrum antiparasitic agent that also have anti-viral activity against a wide range of viruses such as DENV 1-4, West Nile Virus, Venezuelan Equineencephalitis virus, Influenza virus as well as shows its activity against DNA virus, for example, Pseudorabies virus (PRV) in vitro and in vivo due to the reliance by many different RNA viruses on IMP $\alpha / \beta 1$ during infection 54 . It hinders the cooperation between the Human Immunodeficiency Virus-1 (HIV-1) integrase protein (IN) and the importin (IMP) $\alpha / \beta 1$ heterodimer responsible for IN atomic import to restrain viral replication. Another mode of action of ivermectin, it restrains nuclear import of host and viral proteins, including Simian Virus SV40 huge tumor antigen (T-ag) and Dengue Virus (DENV) nonstructural protein 5 55. In an in vitro study, Ivermectin demonstrated to be powerful against SARS-CoV-2 disease by scientists at Monash University in Melbourne, Australia recommends that Vero cells + SARS-CoV-2 for 2 hours, at that point ivermectin was introduced, following 24 hours supernatant viral RNA were diminished and following 48 hours all viral material lost. Further clinical trials should be completed to affirm the viability of medicine in humans with SARS-CoV-2 disease ${ }^{56}$.

\section{Azithromycin}

It is a broad-spectrum antibiotic that may prevent bacterial superinfection, immunomodulators to act as adjuvant therapy in pulmonary inflammatory disorders ${ }^{57}$. They may downregulate the inflammatory reactions by diminishing excessive cytokine production related to respiratory viral infections and immunomodulatory mechanism may incorporate reducing chemotaxis of neutrophils (PMNs) to the lungs by repressing cytokines (i.e., IL-8), restraint of mucus fluid hypersecretion, diminished production of reactive oxygen species, fasting neutrophil apoptosis, and blocking the activation of nuclear interpretation factors 58 . The study suggests that an open-label, non-randomized clinical trial of combination (hydroxychloroquine and azithromycin) administered to prevent bacterial superinfection in 6 patients suggests potential benefit as an adjunct therapy. On day 6 , all patients treated with the combination (hydroxychloroquine and azithromycin) were virally cured compared to patients treated with hydroxychloroquine alone ${ }^{59}$.

\section{Angiotensin-Converting Enzyme Inhibitors (ACEi)}

Early data from China during the SARS-CoV-2 pandemic suggest that patients with hypertension or diabetes are at higher risk of severe SARS-CoV-2 disease ${ }^{60}$. As we as a whole realizes that the receptor for SARS-CoV-2 binds to ACE- 2 and they went into cells and it has been speculated that treatment with ACE-inhibitors (ACEi) or angiotensin receptor blockers (ARB) in such patients may build the expression of ACE-2 ${ }^{60}$. The study in the UK suggests that 
the 205 patients have a lower death rate or ICU admittance within 7 days if a patient on ACE inhibitor and from this study no evidence of ACE inhibitors increase the severity of SARS-CoV-2 infection 61

\section{Corticosteroids}

The corticosteroids like dexamethasone in low dose are under the clinical trials. Corticosteroid therapy is not recommended for viral pneumonia; however, may be used in patients with refractory shock or Acute Respiratory Distress Syndrome 62. No clinical data exist to indicate a benefit from steroids in RSV, Influenza, SARS or MERS potential for harm is increased greater viremia, increased risk of diabetes, and avascular necrosis and psychosis 63 . Low dose dexamethasone may reduce the duration of mechanical ventilation and mortality in Acute Respiratory Distress Syndrome (ARDS) 64

\section{Non-Steroidal Anti- Inflammatory Drugs (NSAIDs)}

The Non-Steroidal Anti-Inflammatory Drug suppresses the Cyclo-oxygenase enzyme-like COX-1 and COX-2 and USFDA keep on exploring the utilization of NSAIDs in patients with SARS-CoV-2 but confirmatory clinical information is missing as of now ${ }^{65}$. There is a recounted distributed letter proposes that a connection among Ibuprofen and expanded ACE-2 expression may prompt more awful results in SARS-CoV-2 patients 66. ESICM and SCCM Surviving Sepsis Campaign proposes that acetaminophen for temperature control in fundamentally sick patients in SARS-CoV-2 67.

\section{Convalescent Plasma Therapy}

Convalescent plasma is versatile immunotherapy used in the prevention and treatment of numerous irresistible ailments for over multi decades in which plasma gathered from donors who recovered from SARS-CoV-2 infection damage may contain antibodies to SARS-CoV-2 disease utilized as prophylaxis or given shortly within 14 days in SARS-CoV-2 patients to dispose of the infection before it makes genuine to lungs ${ }^{68}$. Firstly, in the year 1918 , it was utilized during the deadly influenza flu outbreak and in the year 1930, it was utilized in the treatment of measles ${ }^{69}$. In the year 2014 convalescent plasma gathered from recovered patients of Ebola disease was suggested by WHO as an alternative treatment option during the outbreak, and in the year 2015 , a protocol for the utilization of convalescent plasma in the treatment of Middle East Respiratory Syndrome (MERS) was built up ${ }^{70}$. Till now, more than 1.5 million and more than 300,000 SARS-CoV-2 patients present a significant asset of recovering convalescent plasma ${ }^{71}$. The fundamentals while collecting plasma were mentioned pictorially in Figure 4.

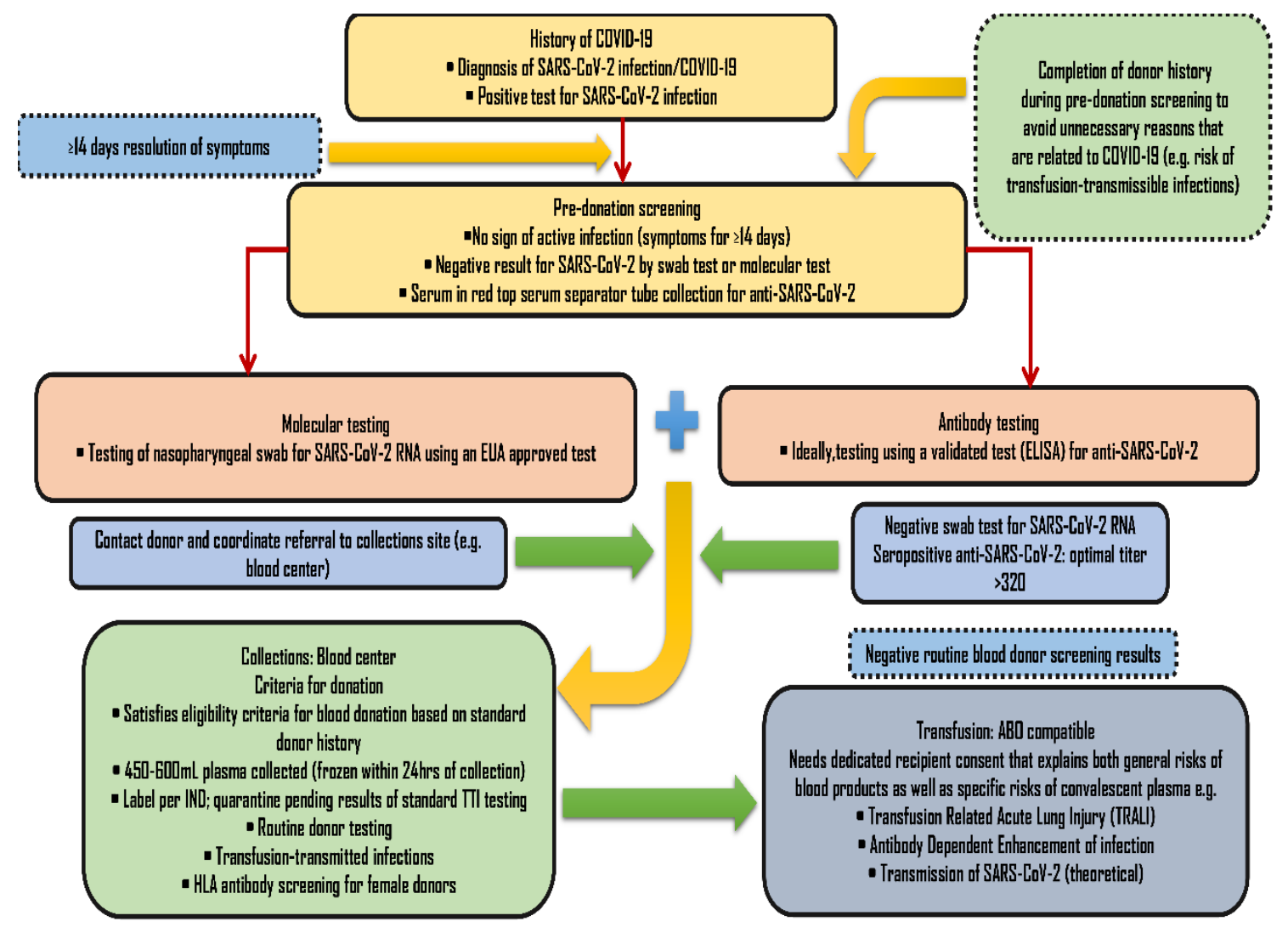

Figure 4: Convalescent Plasma Collections Workflow

\section{Mode of Action of Convalescent Plasma}

The antibodies present in insusceptible for example convalescent plasma intervene in their remedial activity through a variety of mechanisms. Antibodies bind to a given pathogen for example virus, thereby neutralizing its infection directly, while another counter-acting agent intervened pathway, for example, supplement activation, immune response subordinate cell cytotoxicity, or phagocytosis may add to its therapeutic activity. However, passive antibody administration offers an only short-term improvement to confer immediate immunity to susceptible individuals particularly in emerging infectious diseases such as SARS-CoV-2 and human anti-SARS-CoV-2 plasma is the only therapeutic strategy that is quickly available for prevention and treatment of SARS-CoV-2 infection 72 .

\section{Convalescent Plasma Case Studies}

In China, Shen et al. conducted studies in 5 critically ill patients of SARS-CoV-2 disease with convalescent plasma. All 5 patients on IVM received plasma in the range of 10-22 days and the plasma contained IgG and IgM anti-SARS-CoV2 
antibodies. The volume transferred 2 doses of $200 \mathrm{~mL}(\mathrm{x} 2)$ of convalescent plasma with neutralizing antibody titers at $>1: 1000$ and the patient outcome result was normalized body temperature within 3 days in 4 or 5 patients, SOFA score decreases, improved oxygenation like PAO2/FIO2 within 12 days, ARDS resolved in 4 patients at 12 days with reduced inflammation and viral loads become negative after 12 days, ultimately patients recovered from infection 73.

Another contextual investigation in China by Duan et al. conducted, a pilot study in 19 patients, and 9 patients got 1 portion of $200 \mathrm{~mL}$ convalescent plasma with killing neutralizer titers of $>1: 640$ and the middle time from the beginning of ailment to healing plasma transfusion was 16.5 days. Within 3 days, the patients demonstrated improved clinical manifestations alongside an increment of oxyhemoglobin saturation, decreased inflammation, and viral load. The remaining 10 patients among them have a safety study and no adverse effects were reported 74 .

Another investigation in China by Zhang et al. , conducted pilot studies in 4 critically ill patients of SARS-CoV-2 infection with convalescent plasma and the meantime from the onset of illness to plasma was 15.5 days with 1-8 infusion dose of 200-2400 mL with no antibody titers. The patients showed improved clinical symptoms and all patients were recovered and ultimately no adverse effects were reported from transfusion of convalescent plasma 75 .

After further clinical examinations directed in China, their adequacy and their effect on the condition of those treated and recovered patient from SARS-CoV-2 infection, medical hospitals in New York City are getting ready to utilize the plasma blood of those recovered from SARS-CoV-2 infection as a potential remedy for the disease 76 . Also, a little possibility of the risk of utilizing Convalescent Plasma treatment by the transmission of some blood-borne pathogen, for example, Human Immunodeficiency Virus (HIV), Hepatitis B Virus (HBV), or Hepatitis C Virus (HCV) 77. The safety and viability of gaining strength plasma transfusion have not been settled and no conventions exist at present in the United States for SARS-CoV-2 patients yet conventions are allegedly being created at The Johns Hopkins University Hospital. The USFDA has affirmed the utilizing of blood plasma with a high killing antibodies titter from patients who have recovered from SARS-CoV-2 disease and might be an important donor for convalescent plasma 78

\section{The ChAd0x1 nCoV-19 Vaccine}

It is an antibody produced by using an infection (ChAdOx1) which is a weakened version of a typical cold infection (adenovirus) that causes infections in chimpanzees. It is at present under scrutiny for prophylaxis agent against SARS$\mathrm{CoV}-2$ disease yet the viral vector was initially evolved at the University of Oxford's Jenner Institute and Italian Pharmaceutical Manufacturer Advent Srl. against MERS-CoV infection. The hereditary material has been added to the ChAdOx1 vaccine used to make proteins from SARS-CoV-2 infection called spike glycoprotein and taking into account the arrangement of endogenous antibodies against these glycoproteins and thus against the SARS-CoV-2 infection 79. The thought is to show the body to perceive the spike protein of the infection by first presenting it to the ChAdOx1 nCoV-19 vaccine and an immune response is generated when SARSCoV2 enters the body. The vaccine is under the clinical human trials preliminaries Stage 3 under the aegis of the US National Institutes of Health (NIH). For the safety studies, 320 individuals had already been proven but for the efficacy studies, a total of 1,102 individuals was selected across Oxford, Southampton, London, and Bristol 80.

\section{SARS-CoV-2 Phase 1 NCT04283461}

As of 8th April 2020, the worldwide SARS-CoV-2 vaccine includes 115 vaccines out of which 78 are affirmed as dynamic and presently at exploratory or preclinical stages, rest 37 are under development state. The mRNA-1273 is a novel vaccine composed of Lipid Nanoparticle (LNP) encapsulated mRNA based vaccine that encodes a fulllength prefusion stabilized spike (S) protein of SARS-CoV-2, recently under clinical trials by Moderna TX, Inc. which offers great flexibility in terms of antigen manipulation as well as in potential activities. In this Clinical Human Trials, 105 patients were enrolled and administered an intramuscular (IM) injection of mRNA-1273 from Days 1-29 and will be finished in 12 months that provides information about the safety, reactogenicity, and immunogenicity of the vaccine 81

\section{AstraZeneca Case Study to Succumb SARS-CoV-2 Pandemic}

As of 30 April 2020, AstraZeneca and the University of Oxford reported an understanding of the worldwide development and conveyance of the University's recombinant adenovirus immunization vaccine focused on the avoidance of SARS-CoV-2 infection 82. Under the understanding, AstraZeneca would be liable for the development, manufacturing, and distribution of the vaccine at the worldwide level and guarantee that the British individuals and individuals over the world particularly in low and middle-income nations will be shielded from this horrible infection as fast as could reasonably be possible ${ }^{83}$ 85 .

\section{Conclusion}

In a nutshell, the outbreak of SARS-CoV-2 viruses has spread worldwide causes severe illnesses, sustained human-tohuman transmission, and ultimately death making it a serious and public-health concern. Also, it is necessary to make a detailed study of the pathogenic mechanism at the cellular and molecular level as well as the life cycle study of SARS-CoV-2 viruses are also needed. However, the vaccine development efforts and identification of therapeutics including drug repurposing against SARS-CoV-2 infection should be perused on an urgent basis. Furthermore, a broadspectrum anti-viral drug previously used against influenza flu, SARS-CoV, and MERS-CoV can be inspected in future studies. Overall, the control of this ongoing outbreak is a challenge at a worldwide level and it needs our deliberate and immediate action.

\section{References}

1. Surveillances V. The Epidemiological Characteristics of an Outbreak of 2019 Novel Coronavirus Diseases (COVID-19)China, 2020. China CDC Weekly. 2020; 2(8):113-22.

2. Lai CC, Shih TP, Ko WC, Tang HJ, Hsueh PR. Severe acute respiratory syndrome coronavirus 2 (SARS-CoV-2) and corona virus disease-2019 (COVID-19): the epidemic and the challenges. International journal of antimicrobial agents. 2020 Feb 17:105924.

3. Shereen MA, Khan S, Kazmi A, Bashir N, Siddique R. COVID-19 infection: Origin, transmission, and characteristics of human coronaviruses. Journal of Advanced Research. 2020 Mar 16.

4. Yang Y, Peng F, Wang R, Guan K, Jiang T, Xu G, Sun J, Chang C. The deadly coronaviruses: The 2003 SARS pandemic and the 2020 novel coronavirus epidemic in China. Journal of autoimmunity. 2020 Mar 3:102434.

5. Alhazzani W, Møller MH, Arabi YM, Loeb M, Gong MN, Fan E, Oczkowski S, Levy MM, Derde L, Dzierba A, Du B. Surviving Sepsis Campaign: guidelines on the management of critically ill adults 
with Coronavirus Disease 2019 (COVID-19). Intensive care medicine. 2020 Mar 28:1-34.

6. Jewell NP, Lewnard JA, Jewell BL. Caution warranted: using the Institute for Health Metrics and Evaluation model for predicting the course of the COVID-19 pandemic.

7. Grant WB, Lahore H, McDonnell SL, Baggerly CA, French CB, Aliano JL, Bhattoa HP. Evidence that vitamin D supplementation could reduce risk of influenza and COVID-19 infections and deaths. Nutrients. 2020 Apr;12(4):988.

8. of the International CS. The species severe acute respiratory syndrome-related coronavirus: classifying 2019-nCoV and naming it SARS-CoV-2. Nature Microbiology. 2020; 5(4):536.

9. Christian MD, Loutfy M, McDonald LC, Martinez KF, Ofner M, Wong T, Wallington T, Gold WL, Mederski B, Green K, Low DE. Possible SARS coronavirus transmission during cardiopulmonary resuscitation. Emerging infectious diseases. 2004 Feb; 10(2):287.

10. Linton NM, Kobayashi T, Yang Y, Hayashi K, Akhmetzhanov AR, Jung SM, Yuan B, Kinoshita R, Nishiura H. Incubation period and other epidemiological characteristics of 2019 novel coronavirus infections with right truncation: a statistical analysis of publicly available case data. Journal of clinical medicine. 2020 Feb 9(2):538.

11. Moskovitz DN, Van Assche G, Maenhout B, Arts J, Ferrante M Vermeire S, Rutgeerts P. Incidence of colectomy during long-term follow-up after cyclosporine-induced remission of severe ulcerative colitis. Clinical Gastroenterology and Hepatology. 2006 Jun $1 ; 4(6): 760-5$.

12. Zegarra-Valdivia J, Vilca BN, Tairo T, Munive V, Lastarria C. Neurological component in coronaviruses induced disease systematic review of sars-cov, mers-cov, and SARS-CoV-2.

13. Buonaguro L, Tornesello $M$, Buonaguro FJJov. Human immunodeficiency virus type 1 subtype distribution in the worldwide epidemic: pathogenetic and therapeutic implications. 2007;81(19):10209-19.

14. Zhang JJ, Dong X, Cao YY, Yuan YD, Yang YB, Yan YQ, Akdis CA, Gao YD. Clinical characteristics of 140 patients infected with SARS CoV-2 in Wuhan, China. Allergy. 2020 Feb 19.

15. Li W, Shi Z, Yu M, Ren W, Smith C, Epstein JH, Wang H, Crameri G, $\mathrm{Hu}$ Z, Zhang $\mathrm{H}$, Zhang J. Bats are natural reservoirs of SARS-like coronaviruses. Science. 2005 Oct 28; 310(5748):676-9.

16. Lin L, Lu L, Cao W, Li TJEm, infections. Hypothesis for potential pathogenesis of SARS-CoV-2 infection-a review of immune changes in patients with viral pneumonia. 2020; 9(1):727-32.

17. Li X, Geng M, Peng Y, Meng L, Lu S. Molecular immune pathogenesis and diagnosis of COVID-19. Journal of Pharmaceutical Analysis. 2020 Mar 5.

18. Li H, Liu SM, Yu XH, Tang SL, Tang CK. Coronavirus disease 2019 (COVID-19): current status and future perspective. International journal of antimicrobial agents. 2020 Mar 29:105951.

19. Colson P, Rolain JM, Lagier JC, Brouqui P, Raoult D. Chloroquine and hydroxychloroquine as available weapons to fight COVID-19. Int J Antimicrob Agents. 2020 Mar 4; 105932(10.1016).

20. Yan Y, Zou Z, Sun Y, Li X, Xu KF, Wei Y, Jin N, Jiang C. Anti-malaria drug chloroquine is highly effective in treating avian influenza $A$ H5N1 virus infection in an animal model. Cell research. 2013 Feb; 23(2):300-2

21. Zhou D, Dai SM, Tong Q. COVID-19: a recommendation to examine the effect of hydroxychloroquine in preventing infection and progression. Journal of Antimicrobial Chemotherapy. 2020 Mar 20.

22. Devaux CA, Rolain JM, Colson P, Raoult D. New insights on the antiviral effects of chloroquine against coronavirus: what to expect for COVID-19?. International journal of antimicrobial agents. 2020 Mar 12:105938.

23. Gao J, Tian Z, Yang X. Breakthrough: Chloroquine phosphate has shown apparent efficacy in treatment of COVID-19 associated pneumonia in clinical studies. Bioscience trends. 2020.

24. Chu CM, Cheng VC, Hung IF, Wong MM, Chan KH, Chan KS, Kao RY, Poon LL, Wong CL, Guan Y, Peiris JS. Role of lopinavir/ritonavir in the treatment of SARS: initial virological and clinical findings. Thorax. 2004 Mar 1; 59(3):252-6.

25. Liu X, Wang XJ. Potential inhibitors against 2019-nCoV coronavirus $\mathrm{M}$ protease from clinically approved medicines. Journal of Genetics and Genomics. 2020 Feb 20; 47(2):119.

26. Ye XT, Luo YL, Xia SC, Sun QF, Ding JG, Zhou Y, Chen W, Wang XF, Zhang WW, Du WJ, Ruan ZW. Clinical efficacy of lopinavir/ritonavir in the treatment of Coronavirus disease 2019. Eur Rev Med Pharmacol Sci. 2020 Mar 1; 24(6):3390-6.
27. Rahmani H, Davoudi-Monfared E, Nourian A, Khalili H, Hajizadeh N, Jalalabadi NZ, Fazeli MR, Ghazaeian M, Yekaninejad MS Interferon $\beta-1 \mathrm{~b}$ in treatment of severe COVID-19: a randomized clinical trial. International immunopharmacology. 2020 Nov 1 ; 88:106903.

28. ClinicalTrials.gov. Accessed March 18, 2020 https: //clinicaltrials.gov/

29. Dong L, Hu S, Gao J. Discovering drugs to treat coronavirus disease 2019 (COVID-19). Drug discoveries \& therapeutics. 2020 Feb 29; 14(1):58-60.

30. Wenzel RP, Edmond MB. Managing SARS amidst uncertainty. New England Journal of Medicine. 2003 May 15; 348(20):1947-8.

31. Jones BM, Ma ES, Peiris JS, Wong PC, Ho JC, Lam B, Lai KN, Tsang KW. Prolonged disturbances of in vitro cytokine production in patients with severe acute respiratory syndrome (SARS) treated with ribavirin and steroids. Clinical \& Experimental Immunology. 2004 Mar;135(3):467-73.

32. Wang M, Cao R, Zhang L, Yang X, Liu J, Xu M, Shi Z, Hu Z, Zhong W, Xiao G. Remdesivir and chloroquine effectively inhibit the recently emerged novel coronavirus (2019-nCoV) in vitro. Cell research. 2020 Mar; 30(3):269-71.

33. Stockman LJ, Bellamy R, Garner P. SARS: systematic review of treatment effects. PLoS Med. 2006 Sep 12; 3(9):e343.

34. Wang Y, Fan G, Salam A, Horby P, Hayden FG, Chen C, Pan J, Zheng J, Lu B, Guo L, Wang C. Comparative effectiveness of combined favipiravir and oseltamivir therapy versus oseltamivir monotherapy in critically ill patients with influenza virus infection. The Journal of Infectious Diseases. 2020 Apr 27; 221(10):1688-98.

35. Mentré F, Taburet AM, Guedj J, Anglaret X, Keïta S, de Lamballerie $\mathrm{X}$, Malvy D. Dose regimen of favipiravir for Ebola virus disease. The Lancet Infectious Diseases. 2015 Feb 1; 15(2):150-1.

36. Sissoko D, Laouenan C, Folkesson E, M'lebing AB, Beavogui AH, Baize S, Camara AM, Maes P, Shepherd S, Danel C, Carazo S. Experimental treatment with favipiravir for Ebola virus disease (the JIKI Trial): a historically controlled, single-arm proof-ofconcept trial in Guinea. PLoS medicine. 2016 Mar 1; 13(3):e1001967.

37. de Wit E, Feldmann F, Cronin J, Jordan R, Okumura A, Thomas T, Scott D, Cihlar T, Feldmann H. Prophylactic and therapeutic remdesivir (GS-5734) treatment in the rhesus macaque model of MERS-CoV infection. Proceedings of the National Academy of Sciences. 2020 Mar 24; 117(12):6771-6.

38. Sheahan TP, Sims AC, Graham RL, Menachery VD, Gralinski LE, Case JB, Leist SR, Pyrc K, Feng JY, Trantcheva I, Bannister R. Broadspectrum antiviral GS-5734 inhibits both epidemic and zoonotic coronaviruses. Science translational medicine. 2017 Jun 28; 9(396).

39. Martinez MA. Compounds with therapeutic potential against novel respiratory 2019 coronavirus. Antimicrobial agents and chemotherapy. 2020 Apr 21; 64(5).

40. ClinicalTrials.gov. Accessed March 18, 2020. https://clinicaltrials.gov/

41. Khamitov RA, Loginova S, Shchukina VN, Borisevich SV, Maksimov VA, Shuster AM. Antiviral activity of arbidol and its derivatives against the pathogen of severe acute respiratory syndrome in the cell cultures. Voprosy virusologii. 2008; 53(4):9-13.

42. Xu XW, Wu XX, Jiang XG, Xu KJ, Ying LJ, Ma CL, Li SB, Wang HY, Zhang S, Gao HN, Sheng JF. Clinical findings in a group of patients infected with the 2019 novel coronavirus (SARS-Cov-2) outside of Wuhan, China: retrospective case series. bmj. 2020 Feb 19; 368.

43. Wang D, Hu B, Hu C, Zhu F, Liu X, Zhang J, Wang B, Xiang H, Cheng Z, Xiong Y, Zhao Y. Clinical characteristics of 138 hospitalized patients with 2019 novel coronavirus-infected pneumonia in Wuhan, China. Jama. 2020 Mar 17; 323(11):1061-9.

44. Wang Y, Fan G, Salam A, Horby P, Hayden FG, Chen C, Pan J, Zheng J, Lu B, Guo L, Wang C. Comparative effectiveness of combined favipiravir and oseltamivir therapy versus oseltamivir monotherapy in critically ill patients with influenza virus infection. The Journal of Infectious Diseases. 2020 Apr 27; 221(10):1688-98.

45. Huang C, Wang Y, Li X, Ren L, Zhao J, Hu Y, Zhang L, Fan G, Xu J, Gu X, Cheng Z. Clinical features of patients infected with 2019 novel coronavirus in Wuhan, China. The lancet. 2020 Feb 15; 395(10223):497-506.

46. Ströher U, DiCaro A, Li Y, Strong JE, Aoki F, Plummer F, Jones SM Feldmann $H$. Severe acute respiratory syndrome-related coronavirus is inhibited by interferon- $\alpha$. Journal of Infectious Diseases. 2004 Apr 1; 189(7):1164-7. 
47. Zorzitto J, Galligan CL, Ueng JJ, Fish EN. Characterization of the antiviral effects of interferon- $\alpha$ against a SARS-like coronoavirus infection in vitro. Cell research. $2006 \mathrm{Feb} ; 16(2): 220-9$.

48. Haagmans BL, Kuiken T, Martina BE, Fouchier RA, Rimmelzwaan GF, Van Amerongen G, Van Riel D, De Jong T, Itamura S, Chan KH, Tashiro M. Pegylated interferon- $\alpha$ protects type 1 pneumocytes against SARS coronavirus infection in macaques. Nature medicine. 2004 Mar; 10(3):290-3.

49. Loutfy MR, Blatt LM, Siminovitch KA, Ward S, Wolff B, Lho H, Pham DH, Deif H, LaMere EA, Chang M, Kain KC. Interferon alfacon-1 plus corticosteroids in severe acute respiratory syndrome: a preliminary study. Jama. 2003 Dec 24; 290(24):3222-8.

50. Le RQ, Li L, Yuan W, Shord SS, Nie L, Habtemariam BA, Przepiorka D, Farrell AT, Pazdur R. FDA approval summary: tocilizumab for treatment of chimeric antigen receptor $\mathrm{T}$ cell-induced severe or life-threatening cytokine release syndrome. The oncologist. 2018 Aug; 23(8):943.

51. Xu X, Han M, Li T, Sun W, Wang D, Fu B, Zhou Y, Zheng X, Yang Y, Li $X$, Zhang X. Effective treatment of severe COVID-19 patients with tocilizumab. Proceedings of the National Academy of Sciences. 2020 May 19; 117(20):10970-5.

52. Sarosiek S, Shah R, Munshi NC. Review of siltuximab in the treatment of multicentric Castleman's disease. Therapeutic advances in hematology. 2016 Dec; 7(6):360-6.

53. Gritti G, Raimondi F, Ripamonti D, Riva I, Landi F, Alborghetti L, Frigeni M, Damiani M, Micò C, Fagiuoli S, Cosentini R. IL-6 signalling pathway inactivation with siltuximab in patients with COVID-19 respiratory failure: an observational cohort study. medRxiv. 2020 Jan 1.

54. Rizzo E. Ivermectin, antiviral properties and COVID-19: a possible new mechanism of action. Naunyn-schmiedeberg's Archives of Pharmacology. 2020 May 27:1.

55. Neerukonda SN, Katneni U. A Review on SARS-CoV-2 Virology, Pathophysiology, Animal Models, and Anti-Viral Interventions Pathogens. 2020 Jun;9(6):426.

56. Caly L, Druce JD, Catton MG, Jans DA, Wagstaff KM. The FDAapproved drug ivermectin inhibits the replication of SARS-CoV-2 in vitro. Antiviral research. 2020 Apr 3:104787.

57. Amsden GW. Anti-inflammatory effects of macrolides-an underappreciated benefit in the treatment of community-acquired respiratory tract infections and chronic inflammatory pulmonary conditions?. Journal of Antimicrobial Chemotherapy. 2005 Jan 1; 55(1):10-21.

58. Kanoh S, Rubin BK. Mechanisms of action and clinical application of macrolides as immunomodulatory medications. Clinical microbiology reviews. 2010 Jul 1; 23(3):590-615.

59. Gautret P, Lagier IC, Parola P, Meddeb L, Mailhe M, Doudier B, Courjon J, Giordanengo V, Vieira VE, Dupont HT, Honoré S Hydroxychloroquine and azithromycin as a treatment of COVID19: results of an open-label non-randomized clinical trial. International journal of antimicrobial agents. 2020 Mar 20:105949.

60. Salamanna F, Maglio M, Landini MP, Fini M. Body Localization of ACE-2: On the Trail of the Keyhole of SARS-CoV-2. Frontiers in Medicine. 2020 Dec 3; 7:935

61. Bean D, Kraljevic Z, Searle T, Bendayan R, Pickles A, Folarin A Roguski L, Noor K, Shek A, Zakeri R, Shah A. Treatment with ACEinhibitors is associated with less severe disease with SARS-Covid19 infection in a multi-site UK acute Hospital Trust. medRxiv. 2020 Jan 1.

62. Jin YH, Cai L, Cheng ZS, Cheng H, Deng T, Fan YP, Fang C, Huang D, Huang LQ, Huang Q, Han Y. A rapid advice guideline for the diagnosis and treatment of 2019 novel coronavirus (2019-nCoV) infected pneumonia (standard version). Military Medical Research. 2020 Dec $1 ; 7(1): 4$

63. ESICM, SCCM. Surviving sepsis campaign rapid guidelines of the management of critically ill adults with coronavirus disease 2019 (pre-publication). Available on the World Wide Web at: https://www.esicm.org/ssc-covid19-guidelines/.

64. Villar J, Ferrando C, Martínez D, Ambrós A, Muñoz T, Soler JA Aguilar G, Alba F, González-Higueras E, Conesa LA, MartínRodríguez C. Dexamethasone treatment for the acute respiratory distress syndrome: a multicentre, randomised controlled trial. The Lancet Respiratory Medicine. 2020 Mar 1; 8(3):267-76
65. FDA Website: https://www.fda.gov/drugs/drug-safety-andavailability/fda-advises-patients-use-non-steroidal-antiinflammatory-drugs-nsaids-covid-19.

66. Fang L, Karakiulakis G, Roth M. Are patients with hypertension and diabetes mellitus at increased risk for COVID-19 infection?. The Lancet. Respiratory Medicine. 2020 Apr; 8(4):e21.

67. ESICM, SCCM. Surviving sepsis campaign rapid guidelines of the management of critically ill adults with coronavirus disease 2019 (pre-publication). Available on the World Wide Web at: https://www.esicm.org/ssc-covid19-guidelines/.

68. Brown BL, McCullough J. Treatment for emerging viruses convalescent plasma and COVID-19. Transfusion and Apheresis Science. 2020 Apr 20:102790.

69. Zhou B, Zhong N, Guan Y. Treatment with convalescent plasma for influenza A (H5N1) infection. New England Journal of Medicine. 2007 Oct 4; 357(14):1450-1.

70. Van Griensven J, Edwards T, de Lamballerie X, Semple MG, Gallian P, Baize S, Horby PW, Raoul H, Magassouba NF, Antierens A, Lomas C. Evaluation of convalescent plasma for Ebola virus disease in Guinea. New England Journal of Medicine. 2016 Jan 7; 374(1):3342.

71. Chen L, Xiong J, Bao L, Shi Y. Convalescent plasma as a potential therapy for COVID-19. The Lancet Infectious Diseases. 2020 Apr 1; 20(4):398-400.

72. Bloch EM, Shoham S, Casadevall A, Sachais BS, Shaz B, Winters JL, van Buskirk C, Grossman BJ, Joyner M, Henderson JP, Pekosz A. Deployment of convalescent plasma for the prevention and treatment of COVID-19. The Journal of clinical investigation. 2020 Jun $2 ; 130(6): 2757-65$

73. Shen C, Wang Z, Zhao F, Yang Y, Li J, Yuan J, Wang F, Li D, Yang M, Xing L, Wei J. Treatment of 5 critically ill patients with COVID-19 with convalescent plasma. Jama. 2020 Apr 28; 323(16):1582-9.

74. Duan K, Liu B, Li C, Zhang H, Yu T, Qu J, Zhou M, Chen L, Meng S, Hu $\mathrm{Y}$, Peng $\mathrm{C}$. The feasibility of convalescent plasma therapy in severe COVID-19 patients: a pilot study. medRxiv. 2020 Jan 1.

75. Zhang B, Liu S, Tan T, Huang W, Dong Y, Chen L, Chen Q, Zhang L, Zhong Q, Zhang X, Zou Y. Treatment with convalescent plasma for critically ill patients with SARS-CoV-2 infection. Chest. 2020 Mar 31.

76. Jawhara S. Could Intravenous immunoglobulin collected from recovered coronavirus patients protect against COVID-19 and strengthen the immune system of new patients?. International journal of molecular sciences. 2020 Jan; 21(7):2272.

77. MacLennan S, Barbara JA. Risks and side effects of therapy with plasma and plasma fractions. Best Practice \& Research Clinical Haematology. 2006 Mar 1; 19(1):169-89.

78. Abd El-Aziz TM, Stockand JD. Recent progress and challenges in drug development against COVID-19 coronavirus (SARS-CoV-2)-an update on the status. Infection, Genetics and Evolution. $2020 \mathrm{Apr}$ 19:104327.

79. Alharbi NK, Padron-Regalado E, Thompson CP, Kupke A, Wells D Sloan MA, Grehan K, Temperton N, Lambe T, Warimwe G, Becker S. ChAdOx1 and MVA based vaccine candidates against MERS-CoV elicit neutralising antibodies and cellular immune responses in mice. Vaccine. 2017 Jun 27; 35(30):3780-8.

80. Le TT, Andreadakis Z, Kumar A, Roman RG, Tollefsen S, Saville M Mayhew S. The COVID-19 vaccine development landscape. Nat Rev Drug Discov. 2020 Apr 9; 19(5):305-6.

81. NCT04283461 C. Safety and Immunogenicity Study of 2019-nCoV Vaccine (mRNA-1273) for Prophylaxis SARS CoV-2 Infection. ClinicalTrials. gov. 2020.

82. Yamamoto V, Bolanos JF, Fiallos J, Strand SE, Morris K, Shahrokhinia S, Cushing TR, Hopp L, Tiwari A, Hariri R, Sokolov R. COVID-19: review of a 21st century pandemic from etiology to neuro-psychiatric implications. Journal of Alzheimer's Disease. 2020 Jan 1(Preprint):1-45.

83. https://www.astrazeneca.com/media-centre/pressreleases/2020/astrazeneca-and-oxford-university-announcelandmark-agreement-for-covid-19-vaccine.html

84. Bhattacharya, S., Sharma, P., Mathur, H. et al. Recent apprise on coronavirus and its terrible insinuations. VirusDis. 31, 121-127 (2020). https://doi.org/10.1007/s13337-020-00582-2

85. Bhattacharya, Sankha, and Sourabh Kosey. "Quarantine and isolation are the two integral pillars to dodge COVID-19 outbreak." Open Dentistry Journal $14.1 \quad$ (2020). http://dx.doi.org/10.2174/1874210602014010345 